\title{
The Barrier to Access Health Insurance for Maternity Care: Case Study of Female Workers in Indonesia
}

\author{
Qurnia Andayani ${ }^{1}$, Toetik Koesbardiati ${ }^{2}$, Anita Dewi Sujoso ${ }^{3}$, Masruroh $^{4}$, Agung Dwi Laksono ${ }^{5}$ \\ ${ }^{1}$ Doctoral Program, Faculty of Public Health, Universitas Airlangga, Surabaya, Indonesia, ${ }^{2}$ Lecturer, Faculty of \\ Social and Political Science, Universitas Airlangga, Surabaya, Indonesia, ${ }^{3}$ Lecturer, Faculty of Public Health, \\ Jember University East Java, Indonesia, ${ }^{4}$ Lecturer, Faculty of Health Science, Universitas Pesantren Tinggi Darul \\ Ulum Jombang, East Java, Indonesia, ${ }^{5}$ Researcher, National Institute of Health Research and Development of \\ Ministry of Health of the Republic of Indonesia, Jakarta, Indonesia
}

\begin{abstract}
Female workers are one of the vulnerable groups during childbirth. The study is aimed at analyzing the barrier to access health insurance for maternity care among female workers in Indonesia. The samples employed were female worker in childbearing age who had given birth in the last 5 years. The sample size was 18,061 female workers. The variables analyzed included health insurance, healthcare childbirth, type of place of residence, age, education, employment, marital, parity, wealth, know the danger signs of pregnancy, and antenatal care. Determination of determinant by the binary logistic regression. The research results show that female workers who perform maternity care in non-healthcare facilities have 1,142 times the possibility of having health insurance than female workers who perform maternity care in healthcare facilities. It was found that the younger you are, the more likely you are not to have health insurance. Meanwhile, the lower the education and the poorer the female worker, the higher the possibility of not having health insurance. Married female workers have 0.531 times the chance of having health insurance compared to divorced/ widowed female workers. Finally, a female worker that doesn't know the danger signs of pregnancy has 1,076 times the chance of having health insurance than the richest female worker that knows the danger signs of pregnancy. It was concluded that 7 barriers to access health insurance among female workers in Indonesia, namely doing maternity care in non-healthcare facilities, younger age, poor education, single (never in union/divorced/widowed), poor, and don't know the danger signs of pregnancy.
\end{abstract}

Keyword: Female worker, health insurance, maternity care, maternal health.

\section{Introduction}

Maternal Mortality and Child Mortality is the death of a woman while pregnant or within 42 days of termination of pregnancy, irrespective of the duration and site of the pregnancy, from any cause related to or aggravated by the pregnancy or its management but not from accidental or incidental causes ${ }^{1}$.

\section{Corresponding Author:}

\section{Toetik Koesbardiati}

Lecturer, Faculty of Social and Political Science, Universitas Airlangga, Surabaya, Indonesia e-mail: toetik.koesbardiati@fisip.unair.ac.id
Maternal mortality is unacceptably high. About 295 000 women died during pregnancy and childbirth in 2017. The vast majority of these deaths (94\%) occurred in developing countries, and most could have been prevented ${ }^{2}$.Maternal Mortality and Child Mortality in Indonesia is still high, the Maternal Mortality Rate (MMR) in Indonesia ranges from 305 (Supas) to 359 (Susenas) per 100,000 live births. Incidence of multifactorial maternal mortality rate The biggest contributor, about $75 \%$ of maternal deaths, is contributed by direct causes, namely bleeding, infection, hypertension, complications of childbirth, and unsafe abortion ${ }^{3}$.

Nowadays, Female contribute the macroeconomic actively. Female employees actively participate in social labor and become a force that can't be ignored in the 
workplace ${ }^{4}$. Their experience at the workplace affects their well-being, not only at work, but at home and as members of their households and communities. ${ }^{5}$ Female workers and their babies have health risks. The access to health services to maintain their health is important for female workers. A study conducted on 437 female workers in Sidoarjo Indonesia showed that $63.3 \%$ percent of births were assisted by a midwife, $34.3 \%$ were assisted by a doctor and $2.3 \%$ were assisted by a traditional birth attendant ${ }^{6}$. Meanwhile in India, the Accredited Social Health Activist (ASHA) program in India, is to understand the role of community health workers in retaining women in a series of maternity care. ASHA in the community encourages positive health care seeking behavior throughout maternity care ${ }^{7}$.

Insofar as the perceived support received upon arrival of women in health care facilities for different services, namely antenatal, intranatal and postnatal care, the study found that hospitals and health care facilities have different ways of admitting women to hospital. Health facilities for this service. On the one hand, the majority of participants indicated that acceptance of antenatal care services was more supported and accessible. In addition, it was also stated that as far as ANC services were concerned, initial information on childbirth preparedness, family planning and the importance of breasts impressed most women ${ }^{8}$. The three barriers for female worker to increase breastfeeding rates were: breastmilk substitutes marketing practices, the lack of lactation rooms in workplaces, and local customs that may hamper breastfeeding according to recommendations 9 . Optimizing maternity protection programs may result in increased breastfeeding rates ${ }^{9}$.

An exploratory qualitative study in Ethiopia showed that there are twelve homeless mothers who gave birth during childbirth in the last 12 months and 10 health care providers revealed that homeless women did not use any of the basic maternity health care services, namely antenatal care, skilled midwives, and postnatal care. This is due to a lack of premises and permanent awareness, and fear of stigma and discrimination. Other factors related to socio-cultural, socio-economic and health care contribute to the non-use of health services ${ }^{10}$. The utmost success in maternal health will arise if maternal health care services are an unparallel led source for women's healthcare solutions for any problem related to childbirth. Health advocates worldwide claim thateven though maternal services are provided, women's utilization of such services has not been ascertained ${ }^{8}$.
The National Health Insurance is a form of commitment by the Indonesian government to expand access to quality maternal and child health services (KIA), especially for the poor through the birth insurance program (Jampersal), and later in 2014, the National Health Insurance (JKN) introduction. The JKN had an impact on a major restructuring of the public health insurance system by combining all types of public health insurance schemes into JKN, including the combination of benefits including antenatal care, childbirth and postpartum care. The main objective of JKN is social protection to ensure that all people can fulfill their basic needs for proper health ${ }^{1112}$.

There are vulnerabilities in female reproduction include not to get pregnant while working, not having a baby during the contract period, greater wage discrimination for men, including work benefits, such as children and family, less than maximum menstrual and pregnancy leave, harassment, and sexual violence ${ }^{13}$, the lack of lactation room in workplace ${ }^{14}$. The employers display unfavourable attitude towards the employment of childbearing age group women in the first place and pregnancy at workplace ${ }^{12}$. The study is aimed at analyzing the barrier to access health insurance for maternity care among female workers in Indonesia.

\section{Materials and Method}

Data Source: The study employed raw data from the 2017 Indonesian Demographic Data Survey (IDHS) for analysis. The IDHS uses stratification and multistage random sampling to select the required sample. The unit of analysis in this study was female workers of childbearing age (15-49 years), who had given birth in the last 5 years in Indonesia. The sample size used was 18.061 women.

Data Analysis: The dependent variable in this study is health insurance ownership. Health insurance ownership is the respondent's recognition of any type of health insurance. Health insurance ownership is divided into two categories, namely owning and not having.

This study involved 9 independent variables. The nine variables are type of place of residence, type of place of maternity care, age groups, education level, marital status, parity, wealth status, knowledge of the danger of pregnancy, and completeness of antenatal care (ANC). The type of place of residence is divided into 2 categories, namely urban and rural. The type of place of maternity care is divided into 2 categories, namely 
non healthcare facility and healthcare facility. The age groups were divided into 5 years interval. Education level consists of 4 categories, namely no education, primary, secondary and higher. Employment status is divided into 2 categories, namely no employment and employment. Parity is divided into 2 categories, namely primiparous $(\leq 1)$ and multiparous $(>1)$.

Wealth status is determined based on the wealth index calculation. Wealth index is a composite measure of a household's cumulative living standard. The wealth index is calculated using easy-to-collect data on a household's ownership of selected assets, such as televisions and bicycles; materials used for housing construction; and types of water access and sanitation facilities. The wealth index is divided into 5 categories, namely poorest, poorer, middle, richer, and richest. Ownership of health insurance is divided into 2 categories, namely having no and owning.

Know the danger of pregnancy is the respondent's knowledge of the dangers of prolonged labor, vaginal bleeding, fever, convulsions, baby in wrong position, swollen limbs, faint, breathlessness, tiredness, and others. Know the danger of pregnancy is divided into 2 categories, namely not knowing and knowing. ANC is a respondent's visit to get antenatal care during pregnancy at a health care facility. The ANC completeness variable was divided into 2 categories, namely $<4$ visits and $\geq 4$ visits.

Since all the variables involved in this study are dichotomous variables, the chi square test was used at an early stage to see if there were significant differences in health insurance ownership. In the final stage, binary logistic regression is used to determine the barrier to access health insurance among female workers in Indonesia. All statistical analyzes were carried out using SPSS 22 software.

\section{Results and Discussion}

Table 1 is descriptive statistics of health insurance ownership among female workers in Indonesia. It can be seen that all female workers predominantly live in rural areas and choose to give birth in non-healthcare facilities. This condition applies to female workers who have or do not have health insurance.

Table 1. Descriptive statistic of health insurance ownership among female worker in Indonesia $(n=18,061)$

\begin{tabular}{|c|c|c|c|c|c|}
\hline \multirow{3}{*}{ Characteristics } & \multicolumn{4}{|c|}{ Health Insurance Ownership } & \multirow{3}{*}{$\mathbf{P}$} \\
\hline & \multicolumn{2}{|c|}{ Yes } & \multicolumn{2}{|c|}{ No } & \\
\hline & $\mathbf{n}$ & $\%$ & $\mathbf{n}$ & $\%$ & \\
\hline Place of residence & & & & & $* * * 0.000$ \\
\hline - Urban & 5784 & $48.1 \%$ & 2605 & $43.1 \%$ & \\
\hline - Rural & 6234 & $51.9 \%$ & 3438 & $56.9 \%$ & \\
\hline Place of maternity care & & & & & $* * * 0.000$ \\
\hline - Non-healthcare Facilities & 7727 & $64.3 \%$ & 4131 & $68.4 \%$ & \\
\hline - Healthcare Facilities & 4291 & $35.7 \%$ & 1912 & $31.6 \%$ & \\
\hline \multicolumn{6}{|l|}{ Age } \\
\hline$-15-19$ & 59 & $0.5 \%$ & 36 & $0.6 \%$ & \\
\hline$-20-24$ & 585 & $4.9 \%$ & 436 & $7.2 \%$ & \\
\hline$-25-29$ & 1817 & $15.1 \%$ & 1189 & $19.7 \%$ & \\
\hline - 30-34 & 3257 & $27.1 \%$ & 1567 & $25.9 \%$ & \\
\hline - 35-39 & 3531 & $29.4 \%$ & 1618 & $26.8 \%$ & \\
\hline$-40-44$ & 2179 & $18.1 \%$ & 944 & $15.6 \%$ & \\
\hline$-45-49$ & 590 & $4.9 \%$ & 253 & $4.2 \%$ & \\
\hline Education & & & & & $* * * \mathbf{0 . 0 0 0}$ \\
\hline - No education & 348 & $2.9 \%$ & 229 & $3.8 \%$ & \\
\hline - Primary & 3339 & $27.8 \%$ & 2016 & $33.4 \%$ & \\
\hline
\end{tabular}




\begin{tabular}{|c|c|c|c|c|c|}
\hline \multirow{3}{*}{ Characteristics } & \multicolumn{4}{|c|}{ Health Insurance Ownership } & \multirow{3}{*}{$\mathbf{P}$} \\
\hline & \multicolumn{2}{|c|}{ Yes } & \multicolumn{2}{|c|}{ No } & \\
\hline & $\mathbf{n}$ & $\%$ & $\mathbf{n}$ & $\%$ & \\
\hline - Secondary & 5113 & $42.5 \%$ & 3196 & $52.9 \%$ & \\
\hline - Higher & 3218 & $26.8 \%$ & 602 & $10.0 \%$ & \\
\hline Marital & & & & & $* * * 0.000$ \\
\hline - Never in union & 7 & $0.1 \%$ & 2 & $0.0 \%$ & \\
\hline - Married/Livinf with partner & 11633 & $96.8 \%$ & 5656 & $93.6 \%$ & \\
\hline - Divorced/Widowed & 378 & $3.1 \%$ & 385 & $6.4 \%$ & \\
\hline Wealth & & & & & $* * * 0.000$ \\
\hline - Poorest & 3532 & $29.4 \%$ & 2003 & $33.1 \%$ & \\
\hline - Poorer & 1897 & $15.8 \%$ & 1215 & $20.1 \%$ & \\
\hline - Middle & 1927 & $16.0 \%$ & 1069 & $17.7 \%$ & \\
\hline - Richer & 2025 & $16.8 \%$ & 1027 & $17.0 \%$ & \\
\hline - Richest & 2637 & $21.9 \%$ & 729 & $12.1 \%$ & \\
\hline Parity & & & & & 0.245 \\
\hline - Primiparous & 1379 & $11.5 \%$ & 729 & $12.1 \%$ & \\
\hline - Multiparous & 10639 & $88.5 \%$ & 5314 & $87.9 \%$ & \\
\hline \multicolumn{3}{|c|}{ Know the danger signs of pregnancy } & & & $* * * 0.000$ \\
\hline - No & 4290 & $35.7 \%$ & 2536 & $42.0 \%$ & \\
\hline- Yes & 7728 & $64.3 \%$ & 3507 & $58.0 \%$ & \\
\hline ANC visits & & & & & 0.447 \\
\hline$-<4$ times & 7679 & $63.9 \%$ & 3896 & $64.5 \%$ & \\
\hline$-\geq 4$ times & 4339 & $36.1 \%$ & 2147 & $35.5 \%$ & \\
\hline
\end{tabular}

Note: ${ }^{*} \mathrm{p}<0.05 ; * * \mathrm{p}<0.01 ; * * * \mathrm{p}<0.001$.

Based on the age group, the two categories of health insurance ownership were dominated by female workers in the 35-39 age group. Based on the education level, the two categories of health insurance ownership are dominated by female workers with secondary education. Meanwhile, based on marital status, the two categories of health insurance ownership are dominated by married female workers.

Table 1 informs that based on wealth status there is two categories of health insurance ownership that are dominated by the poorest female workers. Based on parity, the two categories of health insurance ownership are dominated by multiparous female workers. Meanwhile, based on knowledge of the danger signs of pregnancy, both categories of health insurance ownership are dominated by female workers who know of the danger signs of pregnancy. Finally, based on ANC visits, both categories of health insurance ownership were dominated by female workers who made ANC visits $<4$ times during pregnancy.

Table 2 is the result of Binary logistic regression of health insurance ownership among female workers in Indonesia. Statistical analysis in this final stage is to determine the barrier to access health insurance among female workers. As a reference, the chosen category have health insurance. 
Table 2. Binary logistic regression of health insurance ownership among female worker in Indonesia $(n=18,061)$

\begin{tabular}{|c|c|c|c|c|}
\hline \multirow{2}{*}{ Predictors } & \multicolumn{4}{|c|}{ Health Insurance Ownership: Don't Have } \\
\hline & Sig. & OR & Lower Bound & Upper Bound \\
\hline Place of residence: Urban & 0.081 & 0.936 & 0.869 & 1.008 \\
\hline Place of residence: Rural & - & - & - & - \\
\hline Place of maternity care: Non-healthcare Facilities & $* * * 0.000$ & 1.142 & 1.061 & 1.230 \\
\hline Place of maternity care: Healthcare Facilities & - & - & - & - \\
\hline Age: $15-19$ & 0.212 & 1.330 & .850 & 2.081 \\
\hline Age: $20-24$ & $* * * 0.000$ & 1.816 & 1.486 & 2.220 \\
\hline Age: $25-29$ & $* * * 0.000$ & 1.940 & 1.634 & 2.303 \\
\hline Age: $30-34$ & $* * * 0.000$ & 1.394 & 1.183 & 1.644 \\
\hline Age: $35-39$ & $* 0.015$ & 1.223 & 1.040 & 1.440 \\
\hline Age: $40-44$ & 0.522 & 1.057 & .892 & 1.252 \\
\hline Age: $45-49$ & - & - & - & - \\
\hline Education: No education & $* * * 0.000$ & 3.479 & 2.833 & 4.271 \\
\hline Education: Primary & $* * * 0.000$ & 3.038 & 2.701 & 3.418 \\
\hline Education: Secondary & $* * * 0.000$ & 3.034 & 2.736 & 3.364 \\
\hline Education: Higher & - & - & - & - \\
\hline Marital: Never in union & 0.155 & 0.311 & 0.062 & 1.558 \\
\hline Marital: Married/Living with partner & $* * * 0.000$ & 0.531 & 0.457 & 0.616 \\
\hline Marital: Divorced/Widowed & - & - & - & - \\
\hline Wealth: Poorest & $* 0.035$ & 1.143 & 1.010 & 1.295 \\
\hline Wealth: Poorer & $* * * 0.000$ & 1.463 & 1.295 & 1.652 \\
\hline Wealth: Middle & $* * * 0.000$ & 1.344 & 1.193 & 1.514 \\
\hline Wealth: Richer & $* * * 0.000$ & 1.394 & 1.240 & 1.566 \\
\hline Wealth: Richest & - & - & - & - \\
\hline Know the danger signs of pregnancy: No & $* 0.037$ & 1.076 & 1.005 & 1.152 \\
\hline Know the danger signs of pregnancy: Yes & - & - & - & - \\
\hline
\end{tabular}

Note: $* \mathrm{p}<0.05 ; * * \mathrm{p}<0.01 ; * * * \mathrm{p}<0.001$

Table 2 shows that female workers who perform maternity care in non-healthcare facilities have 1,142 times the chance of having health insurance than female workers who perform maternity care in healthcare facilities (OR 1,142; 95\% CI 1,061-1,230). The result showed that doing maternity care in non-healthcare facilities is a barrier to access health insurance among female workers in Indonesia. Otherwise, another previous study informed that having health insurance is a determinant of maternity care in healthcare facilities ${ }^{15}$.

Table 2 shows that female workers in the 20-24 age groups were 1,816 times more likely to have health insurance than female workers in the 45-49 age groups (OR 1,816; 95\% CI 1,486-2,220). Meanwhile, female workers in the 35-39 age groups were 1,223 times more likely to have health insurance than female workers in the 45-49 age groups (OR 1,223; 95\% CI 1,040$1,440)$. There is a tendency that younger age is a barrier to access health insurance among female workers in Indonesia. In general, age is also known as a predictor of maternity care in healthcare facilities ${ }^{15}$. Getting older, it is assumed that the more they understand the risks of doing maternity care in non-healthcare facilities ${ }^{16}$. 
Table 2 shows that no education female workers have a 3,479 times chance of having health insurance than female workers with higher education (OR 3,479; 95\% CI 2,833-4,271). Meanwhile, female workers with secondary education have 3,034 times the chance of having health insurance than female workers with higher education (OR 3,034; 95\% CI 2,736-3,364). In education aspect, Poor education is a barrier to access health insurance among female worker in Indonesia. Better education provides a better understanding of health risks ${ }^{17,18}$.

Table 2 shows that a married female worker is 0.531 times more likely to have health insurance than a divorced/widowed female worker (OR $0.531 ; 95 \%$ CI 0.457-0.616). Marital status such as single (divorced/ widowed) is a barrier to access health insurance among female worker in Indonesia. This situation is very risky for women living in Indonesia. In the cultural context in Indonesia, being pregnant without having a husband is a disgrace, so that single women tend to keep their pregnancy secret, do not make ANC visits, and do not carry out maternity care in healthcare facilities ${ }^{19}$.

Table 2 shows that the poorest female worker was 1,143 times more likely to have health insurance than the richest female worker (OR 1,143; 95\% CI 1.0101.295). Female workers in the richest category had 1,394 times the chance of having health insurance than the richest female workers (OR 1,394; 95\% CI 1,240$1,566)$. The analysis shows that poor in wealth status is a barrier to access health insurance among female worker in Indonesia. Several previous studies have also found that this kind of socioeconomic disparities also applies to access to health facilities in general ${ }^{20,21}$.

Table 2 shows that a female worker that doesn't know the danger signs of pregnancy has 1,076 times the chance of having health insurance than the richest female worker that knows the danger signs of pregnancy (OR 1.076; 95\% CI 1.005-1.152). This study found that don't know the danger signs of pregnancy is a barrier to access health insurance among female worker in Indonesia. Female worker's ignorance about the danger sign of pregnancy is in line with poor in education and wealth ${ }^{22}$. The combination ofsuch conditions will further strengthen female workers not to have health insurance.

\section{Conclusions}

Based on the results of the analysis, it can be concluded that there are 7 barriers to access health insurance among female workers in Indonesia. The seven barriers to do maternity care in non-healthcare facilities, younger age, poor education, single (never in union/divorced/widowed), poor, and don't know the danger signs of pregnancy.

Acknowledgments: The author would like to thank the ICF International, who has agreed to allow the 2017 IDHS data to be analyzed in this article.

Source of Funding: Directorate of Research and Community Services Society, Directorate General of Research and Development Strengthening Ministry Research, Technology and Higher Education of the Republic of Indonesia

Conflict of Interest: The authors declare no conflict of interest, financial or otherwise.

Ethical Clearance: The 2017 IDHS has received ethical clearance from the National Ethics Commission. Utilization of the 2017 IDHS data in this study has been permitted by ICF International through its website: https://dhsprogram.com/data/new-user-registration.cfm.

\section{References}

1. World Health Organization. Maternal mortality ratio (per 100000 live births) [Internet]. [cited 2020 Oct 1]. Available from: https://www.who.int/ healthinfo/statistics/indmaternalmortality/en/

2. World Health Organization, UNICEF, UNFPA WBG and the UNPD. Trends in maternal mortality 2000 to 2017: estimates [Internet]. Sexual and Reproductive Health. 2019. 12 p. Available from: https://www.who.int/reproductivehealth/ publications/maternal-mortality-2000-2017/en/

3. Achadi EL. Kematian Maternal dan Neonatal di Indonesia. Rakerkernas 2019. 2019;1-47.

4. Liao Y, Chen J. Tax Cost Control of Personal Remuneration for Female Workers with Two Children under the New Tax Policy. 2019;96(Icemse):430-3.

5. Satrya A, Wulandari P, Pramesti M, Wahyuni S, Zuhdi M. Working Condition and Quality of Life for Female Workers in Garment Factories in Indonesia. 2017;36(Icbmr):335-46.

6. Martiana T, Rochmah TN, Alayyannur PA, Rahman FS. Characteristics of the maternal and child health service of female workers with maternal and child health status in Indonesia. Indian J Public Heal Res 
Dev. 2019;10(5):1499-503.

7. Agarwal S, Curtis S, Angeles G, Speizer I, Singh K, Thomas J. Are community health workers effective in retaining women in the maternity care continuum? Evidence from India. BMJ Glob Heal. 2019;4(4):1-8.

8. Machira K, Palamuleni M. Women's perspectives on quality of maternal health care services in Malawi. Int J Womens Health. 2018;10:25-34.

9. Siregar AYM, Pitriyan P, Walters D, Brown M, Phan LTH, Mathisen R. The financing need for expanded maternity protection in Indonesia. Int Breastfeed J. 2019;14(1):1-10.

10. Gebreyesus H, Mamo A, Teweldemedhin M, Gidey B, Hdush Z, Birhanu Z. Experiences of homeless women on maternity health service utilization and associated challenge in Aksum town, Northern Ethiopia. BMC Health Serv Res. 2019;19(1):1-10.

11. Agustina R, Dartanto T, Sitompul R, Susiloretni KA, Suparmi, Achadi EL, et al. Universal health coverage in Indonesia: concept, progress, and challenges. Lancet. 2019;393(10166):75-102.

12. Anindya K, Lee JT, McPake B, Wilopo SA, Millett $\mathrm{C}$, Carvalho N. Impact of Indonesia's national health insurance scheme on inequality in access to maternal health services: A propensity score matched analysis. J Glob Health. 2020;10(1):1-12.

13. Kabir H, Maple M, Fatema SR. Vulnerabilities of women workers in the readymade garment sector of Bangladesh: A case study of Rana Plaza. J Int Womens Stud. 2018;19(6):224-35.

14. Indrawanto $\mathrm{Y}$, Paramashanti BA, Hadi H, Rahmawati NI, Amna FK. Breastfeeding Support and Facilities for Mothers in the Workplace. J Ners dan Kebidanan Indones [Internet]. 2018;5(3):200-
8. Available from: https://ejournal.almaata.ac.id/ index.php/JNKI/article/view/575

15. Efendi F, Ni'Mah AR, Hadisuyatmana S, Kuswanto H, Lindayani L, Berliana SM. Determinants of facility-based childbirth in Indonesia. Sci World J. 2019;2019.

16. Laksono $\mathrm{AD}$, Wulandari $\mathrm{RD}$. The Barrier to Maternity Care in Rural Indonesia. J Public Heal From Theory to Pract. 2020; Online First.

17. Rohmah N, Yusuf A, Hargono R, Laksono AD, Masruroh, Ibrahim I, et al. Determinants of teenage pregnancy in Indonesia. Indian J Forensic Med Toxicol. 2020;14(3):2080-5.

18. Wulandari $\mathrm{RD}$, Laksono $\mathrm{AD}$. Education as predictor of the knowledge of pregnancy danger signs in Rural Indonesia. Int J Innov Creat Chang. 2020;13(1):1037-51.

19. Pratiwi NL, Fitrianti Y, Nuraini S, Rachmawati T, Laksono AD, Afreni M, et al. Concealed Pregnant Women or Kemel of Gayo Ethnic in Blang Pegayon District, Gayo Lues District, Aceh. Bull Heal Syst Res. 2019;22(2):81-90.

20. Wulandari RD, Qomarrudin MB, Supriyanto S, Laksono AD. Socioeconomic Disparities in Hospital Utilization among Elderly People in Indonesia. Indian J Public Heal Res Dev. 2019;10(11):18004.

21. Wulandari RD, Putri NK, Laksono AD. Socioeconomic Disparities in Antenatal Care Utilisation in Urban Indonesia. Int J Innov Creat Chang. 2020;14(2):498-514.

22. Wulandari RD, Laksono AD. Determinants of knowledge of pregnancy danger signs in Indonesia. PLoS One. 2020;15(5):Article number e0232550. 